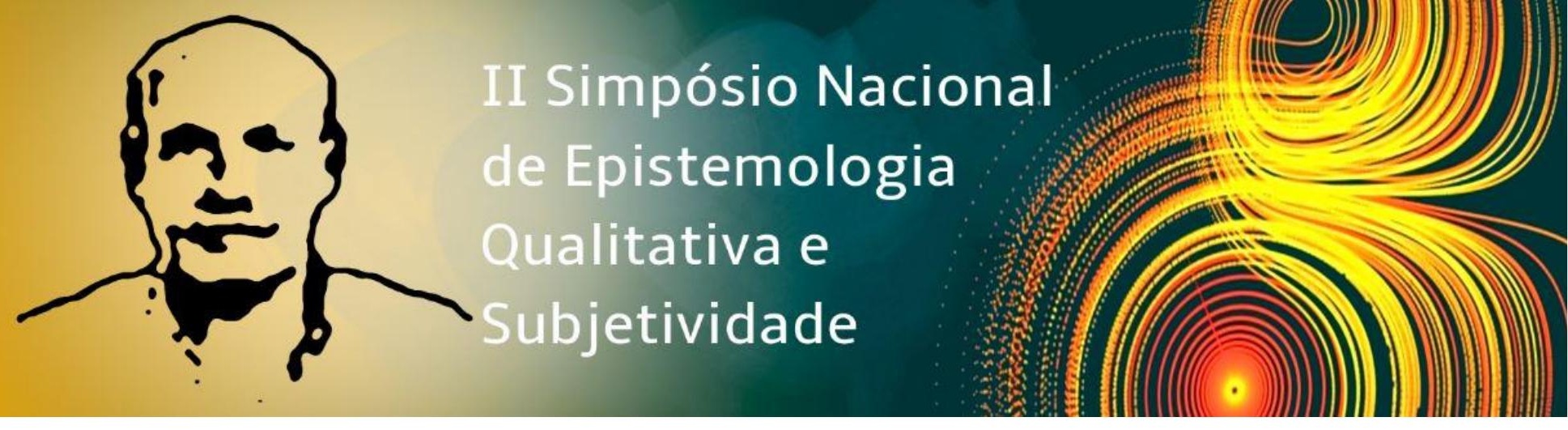

Eixo temático: 6. A subjetividade na Formação de Professores e outros profissionais.

\title{
A Subjetividade do professor e sua expressão na atuação junto aos alunos com desenvolvimento atípico: reflexões para a formação profissional
}

Geandra Claudia Silva Santos, Universidade Estadual do Ceará, geandra.santos@uece.br Bruno de Oliveira Sales Mota, Universidade Estadual do Ceará, oliveira.mota@uece.br

\section{Resumo}

A educação inclusiva desafia o sistema educacional, com impacto concreto na escola, a organizar-se para subsidiar com respostas educacionais os seus alunos, conforme suas demandas de aprendizagem. No Brasil, os marcos regulatórios afinados com a perspecitva inclusiva converteram a Educação Especial em modalidade de educação escolar desenvolvida, centralmente, por meio do atendimento educacional especializado (AEE). Diante desse contexto, o artigo objetiva entender como a configuração subjetiva de uma professora se expressou na sua atuação junto aos alunos com desenvolvimento atípico, no atendimento educacional especializado. A pesquisa foi alicerçada na Epistemologia Qualitativa de González Rey (GONZÁLEZ REY, 2005; GONZÁLEZ REY; MITJÁNS MARTINEZ, 2017) para respaldar as construções teórico-metodológicas, por meio da análise de um caso. Contou com a participação de uma professora do atendimento educacional especializado e outros integrantes de uma escola pública de educação infantil, localizada em um município cearense. A análise respaldou-se na Teoria da Subjetividade na perspectiva Histórico-cultural (GONZÁLEZ REY, (2006; GONZÁLEZ REY; MITJÁNS MARTINEZ, 2017; MITJÁNS MARTÍNEZ; GONZÁLEZ REY, 2017), em que a subjetividade não é uma essência dada, imutável e universal da psique humana, mas um sistema complexo de sentidos subjetivos produzidos na vida cultural, articulando a subjetividade individual e social. Após a análise, compreendemos que a configuração da subjetividade da professora estava constituída por significados sobre deficiência e inclusão fundamentados em perspectiva caritativa e assistencial, bem como fragilidade técnico-científica, acarretando inconsistências nas ações 
